\title{
Resource Boom and Economic Growth: Empirical Evidence from China
}

\author{
Bin Liang ${ }^{1, \text { a }}$, Yiwei Lian ${ }^{2, b}$, Meng Sun ${ }^{3, c}$ \\ ${ }^{1}$ School of Economic and Management, Inner Mongolia University, Huhhot, China \\ ${ }^{2}$ School of Management, Central University of Nationalities, Beijing, China \\ ${ }^{3}$ University of Sydney, Sydney, Australia \\ ahellobin@126.com, blianivy@126.com, ccdjoshua@163.com
}

Keywords: Resource Curse, Industrial Structure, Resource Boom

\begin{abstract}
This study investigates the relationship between resource boom, industrial structure and economic growth of China. Compared with these developed countries with a mature industrial structure, China is still in the process of the industrialization. We first examine the effect of a resource boom in China and provides a quantitative example illustrating that local governments with a resource boom should pay more attention to the initial industrial structure to launch any policy to avoid the "resource curse".
\end{abstract}

\section{Introduction}

The core model of "Dutch disease" is based on the experiences of developed countries, such as Holland and Australia (Bandara, Jayatilleke S. 1995). Comparing to developed countries, the most distinguished features of developing countries, such as China is the immature industrial structure. We propose an alternative mechanism of a resource blessing for the developing countries. The mechanism is based on the interaction between a resource boom, industrial structure and economic growth. We show that a resource boom will change the industrial structure, and if a country has an immature industrial structure, such as a sufficiently large agriculture sector or a small non-resource manufacturing sector, resource boom can enjoy a blessing with a resource boom.

We extend the literature by the following features: examine the impact of a resource boom on the industrial structure and propose that industrial structure condition is an essential factor for an economy with natural abundance; make a clear distinction between resource boom and price boom: a price boom is a rise of price of natural resources, a resource boom is an increase in the stock of natural resources, and narrow our research on the resource boom; focus on the industrial-structure transmission channel of natural resource boom and propose that the initial industrial structure is an essential factor for an economy to experience a blessing or curse with a resource boom.

\section{Empirical analysis}

In this section, we use Chinese city-level data to provide evidence in support of the key predictions of the model. We employ the data of 255 major cities covering 26 provinces taken from volumes of the China City Statistical Yearbook over the period 2001-2011. First, we identify the effect of resource booms on industrial structure. Second, we examines whether there is a resource "curse" or "blessing" in China and then verify the industrial-structure mechanism of a "resource blessing” effect.

Impact of a resource boom on industrial structure. Our model predicts that a natural resource boom has not only the economic growth impact, but also the structural impact on the local economy. We test these hypotheses with Chinese city-level data under the following specification:

$$
I S_{i, t}=\alpha_{0}+\alpha_{1} I S_{i, t-1}+\alpha_{2} \operatorname{Re}_{i, t}+\alpha_{3} V C_{i, t}+\varepsilon_{i, t}
$$


The dependent variable $I S_{i, t}$ is the output share of different sectors over the whole economy. $V C_{i, t}$ represents other control variables, including the degree of openness, institutions and the prices of natural resources. The lagged value of natural resource prices allow us to exploit the significant time variation in the level of the prices, while also mitigating concerns about omitted variable biases and endogeneity. To control for omitted city characteristics, city fixed effects are included and errors are clustered by city. Year fixed effects are also included so as to capture time trends affecting all the cities in the sample. Finally, the level of GDP per capita is also included as a control. Our model predicts not only the structural impact but also the level impact of a resource boom. We also test the level impact predictions with Chinese city-level data and estimate the following specification:

$$
\text { Output }_{i, t}=\alpha_{0}+\alpha_{1} \text { Output }_{i, t-1}+\alpha_{2} \operatorname{Re}_{i, t}+\alpha_{3} V C_{i, t}+\varepsilon_{i, t}
$$

The dependent variable output $t_{i, t}$ is the output level of the different sectors over the whole economy. All the control variables in (2) are the same as (1).

The empirical results of (1) and (2) are shown in Table 1. In line with our theoretical predictions, column 1 and 2 document a negative coefficient on the interaction of resource booms with the output share and level of the agriculture sector. As expected, column 3 and 4 document a positive coefficient on the interaction of resource booms with the output share and level of the industrial sector.

Since "Dutch disease" predicts that "resource curse" arise with a resource boom by shrinking the manufacturing sector, we need to confirm whether our results reflect "Dutch disease" or not. Column6 thus includes interactions of a resource boom with the share of manufacturing sector. Our model shows that a resource boom may shrink the traditional part of the manufacturing sector but will increase the resource-based part of the manufacturing sector. Our findings is opposite with the "Dutch disease" and confirms our model's prediction that a resource boom may shrink the traditional part of the manufacturing sector but increase the resource-based part of the manufacturing sector. Finally, the findings from the regression analysis in column 3 and 4 shows that a resource boom have a significantly positive effect on the output share of the service sector and a significantly negative effect on the output level of the service sector.

Impact of a resource boom on economic growth. We examine whether there is a resource "curse" or "blessing" in China and and estimate the following specification:

$$
y_{t}=\alpha_{0}+\alpha_{1} y_{i, t-1}+\alpha_{2} \operatorname{Re}_{i, t}+\alpha_{3} V C_{i, t}+\varepsilon_{i, t}
$$

Where $i$ represents the prefecture-level city; $t$ represents different years; $\operatorname{Re}_{i, t}$ represents the level of resource abundance; $V C_{i, t}$ represents other control variables in the model, including the degree of openness and institutions and $\varepsilon_{i, t}$ represents the random disturbance term. The results from the system GMM regression models appear in Table 2. Model 1 in Table1 provides supportive evidence that, even after controlling for several additional variables, the coefficients of Re is positive, which reflects a positive association between a resource boom and the growth of the local economy. Our empirical result of "resource blessing” is similar to some literatures (Liu, Chengfang, Linxiu Zhang, Renfu Luo, Scott Rozelle, and Linxiu Zhan 2009).

In order to test the hypothesis 4, we add a cross-product term of $\operatorname{Re}_{i, t}^{2}$ in Model 2 in Table2:

$$
y_{t}=\alpha_{0}+\alpha_{1} y_{i, t-1}+\alpha_{2} \operatorname{Re}_{i, t}+\alpha_{3} V C_{i, t}+\alpha_{4} \operatorname{Re}_{i, t}^{2}+\varepsilon_{i, t}
$$

The coefficient of $\mathrm{Re}_{i, t}^{2}$ in Model 2 of Table1 is significantly negative at the 5\% level. It supports the curvilinear relationship between a resource boom and economic growth predicted by hypothesis 4. If the initial industrial structure is highly resource-based, then there will be less innovation activity with a resource boom and the economic growth will be lower. Hence excess resource dependence will hurt the "resource blessing" effect of the local economy with a resource boom 
(Mavrotas, George, Syed Mansoob Murshed and Sebastian Torres 2011;Van der Ploeg, Frederick 2011).

We also estimate the effect of natural resource prices on the relationship between a resource boom and economic growth. We add the product of the resource abundance and the price of the natural resources ( $\left.\operatorname{Ref} 1_{i, t}\right)$ in Model3 of Table1:

$$
y_{t}=\alpha_{0}+\alpha_{1} y_{i, t-1}+\alpha_{2} \operatorname{Re}_{i, t}+\alpha_{3} V C_{i, t}+\alpha_{4} \operatorname{Re}_{i, t i t}^{2}+\alpha_{5} \operatorname{Ref}_{i, t}+\varepsilon_{i, t}
$$

The coefficient of Ref $1_{i, t}$ in Model 3 is positive, which means the blessing effect of a resource boom will strengthen when there is a price boom of natural resources, and the blessing effect of a resource boom will weaken or even change to be a "curse" when the of natural resources falls.

Above all, we verify that a resource boom may boost the local economic growth, which is opposite to the "Dutch disease" mechanism. Our paper adopted the city-level data of China which is still under industrialization. We show that a resource boom will change the industrial structure of the local economy. If the initial industrial structure is relatively semi-industrialized, a resource boom will help the local economy to upgrade the structure and gain a growth bonus. If the economy is highly resource-based, we also demonstrate that there is little upgrading space left for the resource dependent economy. $R \& D$ is not profitable for a highly resource dependent economy with a resource boom, and there will be less technology progress and therefore a lower economic growth.

Endogeneity issues. Testing the effect of a resource boom using a dynamic panel data requires us to control endogeneity and unobserved heterogeneity. We do so by using a GMM estimator (Arellano, Manuel and Stephen Bond 1991). We used a system GMM estimator (Arellano and Bover, 1995; Blundell and Bond, 1998) instead of a Difference GMM estimator, because the persistence of the dependent performance variable could cause severe weak instrument problems in Difference GMM models. System GMM was estimated using the xtabond2 Stata module (Roodman, David 2009).

Furthermore, our empirical approach has the following features to make it less vulnerable to a potential endogeneity bias. In our paper, we differentiate resource boom and price boom, which have different transmission mechanisms and effects. We propose that extant literature on "resource curse" has failed to distinguish the difference which causes the conflicting results. The price volatility of natural resources has different effects on exploitation and resource-related firms. All the firms in the resource-based sector will benefit from a resource boom. As respect to price booms, Exploitation firms may benefit from a price boom, but some resource-related firms may suffer because the price of resource-related products do not always has the same trend as the natural resources. So we narrow our research to focus on the impacts of resource boom on industrial structure and economic growth and endogeneity will be less of an issue after controlling the prices of natural resources.

This paper uses the data of China, because China experiences a rapid economic growth and industrial upgrading. As a centralized state, China enjoys similar regulations and policies among all regions, which can help us to effectively control the economic and social difference. We also added a fixed province dummy variable to in the analysis process, so as to control the culture differences among different provinces. In this paper, we follow Fan, Fang and Sung(2012) and measure resource abundance by the average fraction of workers in the mining industry compared to the total population in the same city. Some literatures use the ratio of the resource output to total industrial output to measure resource abundance, which itself reflects economic growth. By adopting the share of workers in the mining industry, we can delink resource abundance to economic growth to get rid of the possible endogeneity. 


\section{Conclusions}

This study shows that economies may benefit from a resource boom in an empirical sense. Based on more disaggregated data of China's prefecture-level cities, our empirical analysis shows that there is no "resource curse" effect but "blessing" effect. China's city-level data also supports other results of the theoretical model. The results of this paper do not support that the "resource curse" can be applicable everywhere. A well developed economy with a mature industrial structure may still encounter "resource curse". A developing economy may enjoy "resource blessing" in both theoretical and empirical sense. Therefore local governments with a resource boom should pay more attention to its initial industrial structure, and they should be prudent to launch local policies to suite the transmission mechanism of industrial structure. This paper provides a quantitative example illustrating that when the change of industrial structures incurred by a resource boom may bring "industrial bonus" and help the economy to avoid the "resource curse".

\section{Acknowledgements}

The project is supported by Chinese National Natural Science Foundation of China under Grant No. 71563035, Natural Science Foundation of Inner Mongolia Education Department under Grant No. NJZZ003 and Chinese Education Ministry Foundation under Grant No. IRT1258.

\section{References}

[1] Arellano, Manuel and Stephen Bond. 1991. "Some tests of specification for panel data: Monte Carlo evidence and an application to employment equations." The review of economic studies (The review of economic studies), 58:2, pp. 277-97.

[2] Bandara, Jayatilleke S. 1995. "Dutch Disease in a Developing Country: The Case of Foreign Capital Inflows to Sri Lanka." Seoul Journal of Economics, 8:3, pp. 311-29.

[3] Liu, Chengfang, Linxiu Zhang, Renfu Luo, Scott Rozelle, and Linxiu Zhan. 2009. "Infrastructure Investment in Rural China: Is Quality Being Compromised during Quantity Expansion?" The China Journal (The China Journal):61, pp. 105-29.

[4] Mavrotas, George, Syed Mansoob Murshed and Sebastian Torres. 2011. "Natural resource dependence and economic performance in the 1970-2000 period." Review of Development Economics (Review of Development Economics), 15:1, pp. 124-38.

[5] Roodman, David. 2009. "How to do xtabond2: An introduction to difference and system GMM in Stata." Stata Journal (Stata Journal), 9:1, pp. 86. 
Table 1

The response of the level and share of different sectors to a resource boom

\begin{tabular}{|c|c|c|c|c|c|c|c|}
\hline \multirow{2}{*}{ Dependent variable } & \multicolumn{4}{|c|}{ Share of different sectors } & \multicolumn{3}{|c|}{ Output level of different sectors } \\
\hline & $\begin{array}{l}\text { Share of } \\
\text { agriculture sector }\end{array}$ & $\begin{array}{l}\text { Share of } \\
\text { industrial sector }\end{array}$ & $\begin{array}{l}\text { Share of } \\
\text { manufacturing sector }\end{array}$ & $\begin{array}{l}\text { Share of } \\
\text { service sector }\end{array}$ & $\begin{array}{l}\text { Output of } \\
\text { agriculture sector }\end{array}$ & $\begin{array}{l}\text { Output of } \\
\text { industrial sector }\end{array}$ & $\begin{array}{l}\text { Output of } \\
\text { service sector }\end{array}$ \\
\hline \multirow[t]{2}{*}{ Resource abundance } & $-0.0283 * * *$ & $0.181^{* * *}$ & $0.890 * * *$ & $-0.187 * * *$ & $-0.525 * * *$ & $0.0620^{* *}$ & $0.153^{* *}$ \\
\hline & $(-9.53)$ & $(3.64)$ & $(7.67)$ & $(-12.51)$ & $(-18.55)$ & $(2.26)$ & $(2.49)$ \\
\hline \multirow[t]{2}{*}{ Economic development } & $-0.00911^{* * *}$ & $-0.0464 * * *$ & $0.0442 * * *$ & $0.00637^{* * *}$ & $-0.0551^{* * *}$ & $0.0451 * * *$ & $0.0940 * * *$ \\
\hline & $(-20.83)$ & $(-2.98)$ & $(5.55)$ & $(3.06)$ & $(-11.50)$ & $(5.77)$ & $(8.46)$ \\
\hline \multirow[t]{2}{*}{ Openness } & $-0.223 * * *$ & $-3.720 * * *$ & $2.245^{* * *}$ & $1.936 * * *$ & $-11.23 * * *$ & $3.250^{* * *}$ & $7.017 * * *$ \\
\hline & $(-7.77)$ & $(-3.19)$ & $(3.81)$ & $(10.33)$ & $(-15.66)$ & $(6.44)$ & $(5.55)$ \\
\hline \multirow[t]{2}{*}{ Institution environment } & $-0.0430 * * *$ & 0.0717 & $0.390 * * *$ & $-0.204 * * *$ & $-1.218^{* * *}$ & $-0.553 * * *$ & $-1.490 * * *$ \\
\hline & $(-21.00)$ & $(0.61)$ & $(12.52)$ & $(-11.63)$ & $(-21.69)$ & $(-11.42)$ & $(-16.48)$ \\
\hline \multirow[t]{2}{*}{ Commodity Prices } & $0.00118^{* * *}$ & $0.00288^{* * *}$ & $-0.00638 * * *$ & -0.000299 & $0.0232 * * *$ & -0.000225 & $0.00265 *$ \\
\hline & $(25.63)$ & $(2.97)$ & $(-9.97)$ & $(-1.33)$ & $(35.03)$ & $(-0.55)$ & $(1.96)$ \\
\hline \multirow[t]{2}{*}{ Lagged Variables } & $0.793 * * *$ & $0.633^{* * *}$ & $-0.857 * * *$ & $0.744 * * *$ & $0.892 * * *$ & $0.927 * * *$ & $0.851 * * *$ \\
\hline & $(412.26)$ & $(14.90)$ & $(-42.78)$ & $(60.20)$ & $(215.93)$ & $(148.64)$ & $(38.44)$ \\
\hline \multicolumn{8}{|l|}{ Controls } \\
\hline Province dummy & Yes & Yes & Yes & Yes & Yes & Yes & Yes \\
\hline Time dummy & Yes & Yes & Yes & Yes & Yes & Yes & Yes \\
\hline \multicolumn{8}{|l|}{ Specification tests(p values) } \\
\hline (a)Sargan test & 0.342 & 0.161 & 1.000 & 0.328 & 0.427 & 0.588 & 0.998 \\
\hline (b)second-order serial correlation & 0.222 & 0.716 & 0.560 & 0.346 & 0.129 & 0.135 & 0.461 \\
\hline
\end{tabular}

This table examines the different response of the level and share of different sectors to a resource boom. It shows that a resource boom will significantly increase the shares of industrial sector and its manufacturing sub-sector, and lower the share of agriculture sector. It also shows that a resource boom will significantly increase the output level of industrial and service sector and lower the output level of agriculture sector. T-statistics in parentheses. $* * * * *$, and * indicate significance at $1 \%, 5 \%$, and $10 \%$ level. 
Table 2

\begin{tabular}{|c|c|c|c|}
\hline \multicolumn{4}{|l|}{ The effect of a resource boom on economic growth } \\
\hline & M1 & M2 & M3 \\
\hline \multirow[t]{2}{*}{ Resource abundance } & $(-17.44)$ & $(-13.41)$ & $(-14.48)$ \\
\hline & $1.947^{* * *}$ & $5.938 * * *$ & $5.862^{* * *}$ \\
\hline \multirow[t]{2}{*}{ Economic development } & $(24.56)$ & $(32.61)$ & $(31.95)$ \\
\hline & $-0.343^{* * *}$ & $-0.568 * * *$ & $-0.562 * * *$ \\
\hline \multirow[t]{2}{*}{ Openness } & $(-12.55)$ & $(-19.27)$ & $(-18.82)$ \\
\hline & $9.140^{* * *}$ & $17.65^{* * *}$ & $16.19 * * *$ \\
\hline \multirow[t]{2}{*}{ Institution environment } & $(6.69)$ & $(9.75)$ & $(8.32)$ \\
\hline & $1.216^{* * *}$ & $2.903^{* * *}$ & $2.728 * * *$ \\
\hline \multirow[t]{2}{*}{ Commodity Prices } & $(7.16)$ & $(11.11)$ & $(10.55)$ \\
\hline & $0.0139 * * *$ & $0.0206^{* * *}$ & $0.0149 * * *$ \\
\hline \multirow[t]{2}{*}{ Lagged Variables } & $-0.0479 * * *$ & $-0.0609 * * *$ & $-0.0590 * * *$ \\
\hline & $-0.0479 * * *$ & $-0.0609 * * *$ & $-0.0590 * * *$ \\
\hline Province dummy & Yes & Yes & Yes \\
\hline Time dummy & Yes & Yes & Yes \\
\hline \multirow[t]{2}{*}{ Resource abundance * Resource abundance } & & $-5.197 * * *$ & $-5.256 * * *$ \\
\hline & & $(-17.60)$ & $(-18.27)$ \\
\hline \multirow[t]{2}{*}{ Resource abundance * share of agriculture sector } & & & $0.0791^{* * *}$ \\
\hline & & & $(5.35)$ \\
\hline \multicolumn{4}{|l|}{ Specification tests(p values) } \\
\hline (a)Sargan test & 0.931 & 0.990 & 0.988 \\
\hline (b)second-order serial correlation & 0.211 & 0.356 & 0.296 \\
\hline
\end{tabular}

This table examines the relationship of a resource boom and economic growth. Model 1 examines whether there is a resource "curse" or "blessing" in China and shows that a resource boom will boost the economic growth. Model 2 examines whether there is a curvilinear relationship between a resource boom and economic growth and shows that the effect of a resource boom on economic growth is converse $\mathrm{U}$ shaped. Model 3 examines the effect of natural resource prices on the relationship between a resource boom and economic growth. T-statistics in parentheses. ${ }^{* * *}, * *$, and $*$ indicate significance at $1 \%, 5 \%$, and $10 \%$ level. 